\title{
cDNA Cloning and Functional Expression of the $\alpha$-D-Galactose-Binding Lectin Frutalin in Escherichia coli
}

\author{
Carla Oliveira $\cdot$ Sofia Costa $\cdot$ José A. Teixeira \\ Lucília Domingues
}

Published online: 12 June 2009

(C) Humana Press 2009

\begin{abstract}
DNA clones encoding frutalin, the $\alpha$-D-galactose-binding lectin expressed in breadfruit seeds (Artocarpus incisa), were isolated and sequenced. The deduced amino acid sequences indicated that frutalin may be encoded by a family of genes. The NCBI database searches revealed that the frutalin sequence is highly homologous with jacalin and morni$\mathrm{gaG}$ sequences. Frutalin cDNA was re-amplified and cloned into the commercial expression vector pET-25b(+) for frutalin production in Escherichia coli. An experimental factorial design was employed to maximise the soluble expression of the recombinant lectin. The results indicated that temperature, time of induction, concentration of IPTG and the interaction between the concentration of IPTG and the time of induction had the most significant effects on the soluble expression level of recombinant frutalin. The optimal culture conditions were as follows: induction with $1 \mathrm{mM}$ IPTG at $22^{\circ} \mathrm{C}$ for $20 \mathrm{~h}$, yielding $16 \mathrm{mg} / \mathrm{l}$ of soluble recombinant frutalin. SDS-PAGE and Western blot analysis revealed that recombinant frutalin was successfully expressed by bacteria with the expected molecular weight $(17 \mathrm{kDa})$. These analyses also showed that recombinant frutalin was mainly produced as insoluble protein. Recombinant frutalin produced by bacteria revealed agglutination properties and carbohydrate-binding specificity similar to the native breadfruit lectin.
\end{abstract}

Keywords Galactose-binding jacalin-related lectin . Frutalin cDNA cloning $\cdot$ Escherichia coli expression system · Experimental factorial design . Hemagglutination activity

C. Oliveira $\cdot$ S. Costa $\cdot$ J. A. Teixeira $\cdot$ L. Domingues $(\varangle)$ IBB-Institute for Biotechnology and Bioengineering, Centre of Biological Engineering, Universidade do Minho, Campus de Gualtar, 4710-057 Braga, Portugal

e-mail: luciliad@deb.uminho.pt

\section{Introduction}

Lectins are a heterogeneous group of proteins of nonimmune origin that possess at least one non-catalytic domain which bind reversibly to specific mono- or oligosaccharides [1]. They can be found in several organisms, namely viruses, bacteria, animals and plants, but the plant seeds are the major source of lectins [2]. Plant lectins are involved in various biological recognition phenomena due to their ability to specifically bind certain carbohydrates $[3,4]$.

Frutalin is the major lectin of Artocarpus incisa seeds (or Artocarpus altilis), a plant generally known as breadfruit. This lectin is a tetrameric glycoprotein that specifically recognises $\alpha$-D-galactose residues [5]. It belongs to the jacalin-related lectins family, more precisely to the galactose-binding sub-family, as it presents high similarities in sequence, structure and sugar specificity with the jacalin lectin (the galactose-specific lectin of A. integrifolia seeds-jackfruit, the first member of this family to be identified) [5, 6, this work]. Frutalin also presents functional properties identical to jacalin; however, it has a more noticeable biological activity than the jackfruit lectin, as shown by its higher hemagglutination activity [7]. Previous studies have shown that frutalin plays an important role in many biomedical applications. This lectin was able to induce mice neutrophil migration in vivo, and to be a potent direct chemotactic for human neutrophils and stimulator of human lymphocytes, both in vitro [8, 9]. Considering the potential biological applications of frutalin, it is very important to develop a strategy to increase its production. The expression of frutalin in heterologous systems, such as yeast or bacteria, may improve its availability and also offers a mean to obtain pure lectin of defined amino acid sequence. The isoforms of frutalin, 
having different binding affinities and/or specificities, may introduce additional unwanted variability when used, for instance, as a diagnostic tool. The methylotrophic yeast Pichia pastoris has already been successfully used for frutalin production, using an optimised synthetic gene encoding a mature frutalin protein sequence [10]. The bacteria Escherichia coli was also chosen as a host for frutalin production as this expression system offers a rapid and economical way to produce unglycosylated recombinant frutalin. Moreover, several functional plant lectins have been successfully expressed in $E$. coli, such as jacalin (Artocarpus integrifolia) [11], GNA (Galanthus nivalis) [12], Oryza sativa agglutinin [13] or PCL (Pinellia cordata) [14], amongst others.

This article reports the molecular cloning of frutalin cDNA, analysis of the deduced amino acid sequences and optimisation of the expression and purification of the recombinant frutalin produced by $E$. coli. By implementing an experimental factorial design, the effects on soluble recombinant frutalin expression of the IPTG concentration, the temperature and time of induction, and the interactions between them, were evaluated and the optimal culture conditions determined. The sugar specificity of the recombinant frutalin obtained was also studied by hemagglutination assays and compared to that of the native frutalin.

\section{Materials and Methods}

Frutalin cDNA Synthesis, Cloning and Sequencing

Total RNA was isolated from immature breadfruit seeds from Brazil using the RNeasy Plant Mini kit (Qiagen) and the RT-PCR reaction (reverse transcriptase-polymerase chain reaction) was carried out using the Ready-To-GO ${ }^{\mathrm{TM}}$ RT-PCR Beads kit (Amersham Pharmacia Biotech), following the manufacturer instructions. The cDNA was amplified by PCR as follows: denaturation at $42^{\circ} \mathrm{C}$ for $40 \mathrm{~min}$ and $95^{\circ} \mathrm{C}$ for $4 \mathrm{~min}$; 40 amplification cycles at $92^{\circ} \mathrm{C}$ for $1 \mathrm{~min}, 50^{\circ} \mathrm{C}$ for $2 \mathrm{~min}$ and $72^{\circ} \mathrm{C}$ for $3 \mathrm{~min}$; and a final elongation step of $72^{\circ} \mathrm{C}$ for $10 \mathrm{~min}$. The primers used were designed based on the amino acid sequence of mature frutalin.

The amplified product (483 bp) was purified from $1 \%$ agarose gel using the GFX DNA purification kit (Amersham Biosciences) and cloned into chemically competent E. coli One Shot ${ }^{\circledR}$ Match $1^{\mathrm{TM}}-\mathrm{T} 1^{\mathrm{R}}$ cells that carries the plasmid pCR ${ }^{\circledR} 4-$ TOPO $^{\circledR}$ (Invitrogen). The cDNA library was then propagated in LB medium plates supplemented with $100 \mu \mathrm{g} / \mathrm{ml}$ of ampicillin. Recombinant plasmids were prepared from E. coli transformants using the QIAprep ${ }^{\circledR}$ Spin Miniprep kit (Qiagen), and a T7 commercial primer
(Invitrogen) and frutalin-specific primers were used to sequence the inserts.

Frutalin Properties and Homology Search

The putative frutalin molecular weight $\left(M_{\mathrm{w}}\right)$ and isoelectric point $(\mathrm{p} I)$ values were calculated using Compute $\mathrm{pI} / \mathrm{Mw}$ tool online (http://www.expasy.ch/tools/pi_tool.html).

The identity of the frutalin-deduced amino acid sequences with other lectins was analysed at the NCBI website (http://www.ncbi.nlm.nih.gov).

\section{Construction of the Expression Plasmid}

Specific primers were designed to amplify and sub-clone one of the frutalin cDNA sequences obtained into the multiple cloning site of the $\mathrm{pET}-25 \mathrm{~b}(+)$ expression vector (Novagen). The forward primer used was 5'-CTC CC ATG GCA GAA CAA AGC GGG AAG AGC CAG ACT GTA ATA GTA GGA $C C T$ TGG GGA G-3' and the reverse primer was 5'-CAC CTC GAG TCA AAG GGA CAA GTA CAT GC- $3^{\prime}$. The restriction cloning sites $N c o$ I and XhoI (underlined) were included in the forward and in the reverse primers, respectively, and a stop codon (in bold) was also included in the reverse primer. Since the frutalin gene has an internal NcoI restriction site (located at the 14 th/15th codon position), the correspondent proline codon CCA was changed to the equivalent CCT codon in the forward primer (in italic). Also, the frutalin N-terminal aspargine codon was replaced with an alanine codon in the forward primer. The ATG sequence present in the NcoI site acts as the initiation codon for the translation of the mature frutalin polypeptide.

The PCR reaction was performed as follows: preheating at $95^{\circ} \mathrm{C}$ for $5 \mathrm{~min} ; 30$ amplification cycles at $95^{\circ} \mathrm{C}$ for $45 \mathrm{~s}$, $60^{\circ} \mathrm{C}$ for $45 \mathrm{~s}$ and $72^{\circ} \mathrm{C}$ for $1 \mathrm{~min}$; and a final elongation step of $72^{\circ} \mathrm{C}$ for $10 \mathrm{~min}$, using Vent DNA Polymerase (Stratagene). The PCR product was digested with the enzymes NcoI and XhoI (Roche) and cloned into the same restriction sites of the $\mathrm{pET}-25 \mathrm{~b}(+)$, using T4 DNA ligase (Promega). LB medium plates, supplemented with $100 \mu \mathrm{g} /$ $\mathrm{ml}$ of ampicillin, were used for $E$. coli recombinants selection and maintenance. The $\mathrm{pET}-25 \mathrm{~b}(+)$ insert was sequenced to insure that the frutalin gene modifications introduced were successfully amplified in the PCR product.

\section{Recombinant Frutalin Expression Experiments}

Escherichia coli BL21-CodonPlus(DE3)-RIPL (Stratagene) cells were transformed with the $\mathrm{pET} 25 \mathrm{~b}(+)$ vector harbouring the frutalin codifying gene. The recombinant strain was grown at $37^{\circ} \mathrm{C}$ in $\mathrm{LB}$ medium, supplemented with $100 \mu \mathrm{g} / \mathrm{ml}$ of ampicillin and $50 \mu \mathrm{g} / \mathrm{ml}$ of chloramphenicol, 
to an $\mathrm{OD}_{600}$ of 0.5 . At this point, isopropyl- $\beta$-D-thiogalactopyranoside (IPTG) was added to the desired final concentration and the induction was carried out for different time periods at different temperatures, according to the experimental factorial design. After the expression experiments, $E$. coli cells were harvested by centrifugation (15 min, $10,000 \mathrm{~g}, 4^{\circ} \mathrm{C}$ ), and re-suspended in PBS buffer ( $8 \mathrm{~g} / \mathrm{l} \mathrm{NaCl}, 0.2 \mathrm{~g} / \mathrm{l} \mathrm{KCl}, 2.68 \mathrm{~g} / \mathrm{l} \mathrm{Na} \mathrm{HPO}_{4} \cdot 7 \mathrm{H}_{2} \mathrm{O}$ and $0.24 \mathrm{~g} / 1 \mathrm{KH}_{2} \mathrm{PO}_{4}$, pH 7.4 adjusted with $\mathrm{HCl}$ ) supplemented with $1 \mathrm{mM}$ of phenylmethylsulfonylfluoride (1/100 of the initial medium volume). Cells were disrupted by sonication on ice (Branson Sonifier, 5 min, duty cycle 50\%, output 5) and the insoluble debris recovered by centrifugation (30 $\mathrm{min}, 10,000 \mathrm{~g}, 4^{\circ} \mathrm{C}$ ). The $E$. coli soluble and insoluble fractions were analysed for the presence of recombinant frutalin by denaturing SDS-PAGE electrophoresis and Western blot analyses, as previously described [10]. The primary antibody was polyclonal anti-frutalin, the secondary antibody was "anti-rabbit IgG peroxidase" (Sigma) and DAB (3,3'-diaminobenzidine, Sigma) was used to specifically detect membrane-bound secondary antibody. Soluble recombinant frutalin was quantified on scanned gels using the Quantity One software (Bio-Rad). BSA was applied on gels at defined concentrations and used as a standard for the quantification of soluble recombinant frutalin.

\section{Experimental Factorial Design}

An experimental factorial design was implemented to maximise the soluble expression of recombinant frutalin in $E$. coli. Factors known to affect the expression level of soluble recombinant proteins in $E$. coli were considered for the design, namely the IPTG concentration, the temperature and the time of induction. Each factor was restricted to two levels, a lower level $((-)$ level) and an upper level $((+)$ level) (Table 1). A $2^{3}$ full-factorial experimental design was implemented containing all combinations of the twolevel codes on the three factors: IPTG concentration $(0.1$ and $1 \mathrm{mM}$ ), temperature $\left(22\right.$ and $37^{\circ} \mathrm{C}$ ) and time ( 3 and $20 \mathrm{~h})$. The combinations resulted in eight different expression experiments, which were performed in triplicate. Four repetitions of a 9th experiment, at the centre point level $\left(0.55 \mathrm{mM}\right.$ of IPTG, $29.5^{\circ} \mathrm{C}$ and $\left.11.5 \mathrm{~h}\right)$, were also performed to determine if there is a non-linear relationship between the variables and the responses. The average effect, the main effects (the effect of each individual variable on the response), the two-factor and the three-factor interactions effects were estimated by using the Design Expert 7.1.6 software (trial version). The effects that had a $P$-value $<0.05$ were considered significant. The significant effects affecting the soluble expression of recombinant frutalin were identified and evaluated, and the optimum culture conditions determined. The concentration of soluble recombinant frutalin was expressed as a function of the significant factors in a polynomial model.

\section{Recombinant Frutalin Purification}

Recombinant frutalin, produced at the determined optimal culture conditions (induction with $1 \mathrm{mM}$ IPTG at $22^{\circ} \mathrm{C}$ for $20 \mathrm{~h}$ ), was purified from $E$. coli cultures by size-exclusion chromatography followed by ion-exchange chromatography. The E. coli cell-free extracts were filtered through $0.22-\mu \mathrm{m}$ pore size filters and then loaded onto a Sephacryl ${ }^{\circledR}$ S-100 HR column using a FPLC system (both from Pharmacia Biotechnology), which had been previously equilibrated with PBS buffer at a flow rate of $1 \mathrm{ml} / \mathrm{min}$. The presence of the recombinant lectin in the collected fractions ( $2 \mathrm{ml}$ each) was verified by agglutination activity assays with rabbit erythrocytes (without diluting the fractions). The protein content of fractions positive for hemagglutination was determined by SDS-PAGE electrophoresis followed by silver nitrate staining. Those fractions were combined and dialysed against $10 \mathrm{mM}$ acetate buffer, $\mathrm{pH}$ 5.0 (overnight at $4^{\circ} \mathrm{C}$ ) and further purified and concentrated by ion-exchange chromatography, using a Mono-S column (Amersham Pharmacia) and the FPLC system. Recombinant frutalin was eluted from this column with a gradient of 150-200 $\mathrm{mM}$ of $\mathrm{NaCl}$ and dialysed against PBS buffer (overnight at $4^{\circ} \mathrm{C}$ ). Purified protein was visualised on SDSPAGE gels stained with silver nitrate and quantified using the Coomassie Plus Assay Kit from Pierce.

\section{Hemagglutination Assays}

Two-fold diluted samples of lectin (final volume of $50 \mu \mathrm{l}$ ) were mixed in $1.5 \mathrm{ml}$ eppendorfs with $50 \mu \mathrm{l}$ of a $2 \%(\mathrm{v} / \mathrm{v})$ suspension of rabbit erythrocytes. The lectin samples and the erythrocytes suspension were prepared in PBS buffer. Then, mixtures were incubated at $37^{\circ} \mathrm{C}$ for $30 \mathrm{~min}$, followed by an overnight incubation at room temperature. The highest dilution of lectin that still exhibited visible agglutination was recorded.

The inhibition of the lectin-induced hemagglutination by carbohydrates was determined as follows. Lectin samples,

Table 1 Specification of variables and experimental domain of the experimental factorial design implemented for the optimisation of soluble recombinant frutalin expression in E. coli

\begin{tabular}{llll}
\hline Variables & \multicolumn{2}{l}{ Domain } & \\
\cline { 2 - 4 } & $(-)$ level & $(0)$ level & $(+)$ level \\
\hline$x_{1}$ : Temperature of induction $\left({ }^{\circ} \mathrm{C}\right)$ & 22 & 29.5 & 37 \\
$x_{2}:$ Concentration of IPTG $(\mathrm{mM})$ & 0.1 & 0.55 & 1 \\
$x_{3}:$ Time of induction $(\mathrm{h})$ & 3 & 11.5 & 20 \\
\hline
\end{tabular}


at their minimal agglutinating concentration, were added to each sugar solution tube (250 mM, prepared in PBS buffer) and the mixtures were incubated for $30 \mathrm{~min}$ at room temperature (final volume of $50 \mu \mathrm{l}$ ). Then, $50 \mu \mathrm{l}$ of a $2 \%(\mathrm{v} / \mathrm{v})$ suspension of rabbit erythrocytes were added to the lectinsugar solution tubes, incubated at $37^{\circ} \mathrm{C}$ for $30 \mathrm{~min}$, followed by an overnight incubation at room temperature. The sugars that visibly inhibited or not the agglutination of the rabbit erythrocytes were identified. A positive control, containing PBS instead of any sugar, was also made.

Native frutalin, purified as previously described [5], was also studied in these assays.

\section{Results and Discussion}

\section{Molecular Cloning of the Frutalin cDNA}

A cDNA library was constructed with $A$. incisa RNA using synthetic oligonucleotides based on an amino acid sequence of mature frutalin. The screening of the library yielded multiple positive clones encoding frutalin. Sequence analysis of the cDNA clones revealed that each contained $471 \mathrm{bp}$, which corresponds to a protein of 157 amino acids, with a calculated molecular weight of $17.1 \mathrm{kDa}$ and a predicted isoelectric point of 8.75. From these 157 amino acids, 20 amino acids correspond to the $\beta$-chain, 4 amino acids to the linker "T-S-N-N" and the final 133 amino acids correspond to the $\alpha$-chain (from $\mathrm{N}$-terminal to $\mathrm{C}$-terminal) (Fig. 1). This is in agreement with amino acid sequencing studies which have shown that the primary structure of frutalin consists of a heavy chain of 133 amino acids ( $\alpha$-chain) non-covalently bound to a light chain of 20 amino acids ( $\beta$-chain). In fact, the linker tetrapeptide is not a component of mature frutalin, as it is excised during lectin processing to separate frutalin $\beta$ - and $\alpha$-chains. This processing step is a characteristic of the sub-group of the galactose-binding jacalin-related lectins, which does not occur in the sub-group of the mannose-binding lectins [15].

The analysis of multiple frutalin cDNA clones showed that frutalin is made of several slightly different codifying DNA sequences, which indicates that frutalin may be encoded by a multi-gene family. It has previously been reported that jacalin is encoded by a large family of genes at multiple loci in the A. integrifolia genome [16]. Furthermore, the different cDNA clones may encode different mature frutalin isoforms found in breadfruit seeds. Table 2 shows the amino acid differences found between three different frutalin codifying genes and a frutalin mature sequence. These variations were observed in 15 residues from the 157 amino acids of the mature frutalin sequence; clone A presented 11, clone B 10 and clone C 12 amino acid differences. Between the deduced amino acid sequences (clones A, B and C), 4-10 amino acid substitutions can be observed, which are mostly located in the $\alpha$ chain. Similar variations were observed in jacalin, where a total of 10-13 amino acid substitutions were found [1619]. Deduced amino acid sequences with or without consensus sequences for $N$-glycosylation (Asn-X-Thr/Ser) in $\alpha$-chain were found. This is corroborated by the presence of both non-glycosylated and glycosylated forms in mature frutalin. Furthermore, it was identified a potential $\mathrm{N}$-glycosylation site, also reported for mature jacalin protein [17], located in the $\alpha$-chain at position Asn67 (Fig. 1).

Sequence Similarity Between Frutalin and Other Lectins

The deduced amino acid sequences of frutalin showed a very high homology and sequence similarity with the deduced amino acid sequences of cDNA clones encoding other galactose-binding plant lectins, namely jacalin and mornigaG (Moraceae family) [16, 20], as demonstrated by the alignment in Fig. 1. The alignments revealed amino acid identities up to $95 \%$ between frutalin and jacalin sequences and up to $76 \%$ between frutalin and mornigaG sequences. The amino acid composition of the frutalin linker presents $100 \%$ of identity with the amino acid composition of the linker of the referred lectins. The deduced amino acid sequences of frutalin also presented high sequence similarity with other Moraceae galactosebinding lectins from different species of the Artocarpus genus, such as with the $\beta$-chain and the $\mathrm{N}$-terminal of the $\alpha$-chain of A. integer [21] and A. tonkinensis lectins [22], as well as with the $\alpha$-chain of the lectin from Maclura pomifera specie [18]. These results suggest that amino acid sequences of the plant galactose-binding lectins are well conserved in the Moraceae family. Moreover, reasonable sequence similarity between frutalin and mannose-binding jacalin-related lectins was observed, namely for mornigaM (Morus nigra, up to 57\% amino acid identity) [20] and $\mathrm{KM}+$ (A. integrifolia, up to 55\% amino acid identity) [23].

\section{Expression of Recombinant Frutalin in E. coli}

The E. coli expression system was considered for frutalin production because native frutalin post-translational modifications do not seem to be important for the sugar specificity and functionality of galactose-binding jacalin-related lectins [10, 11, 24]. Furthermore, E. coli is the simplest and the most economical host for recombinant protein production [25].

A frutalin cDNA sequence obtained by RT-PCR, encoding a mature frutalin isoform, was used for frutalin 


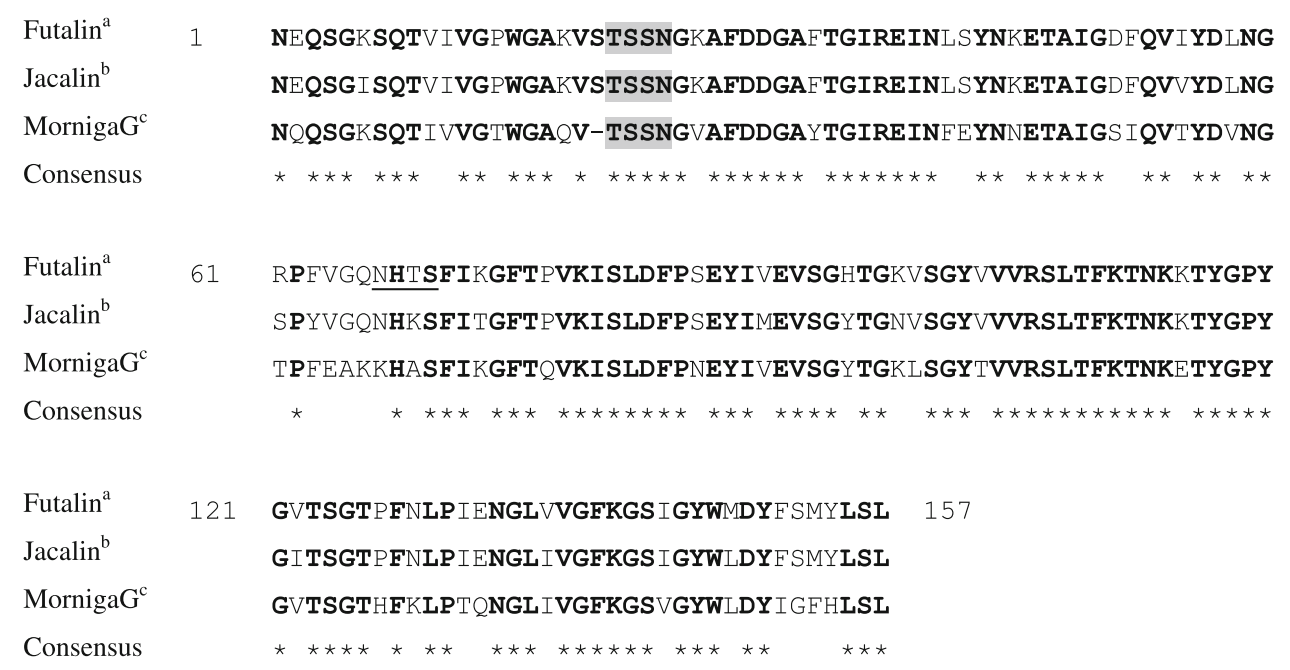

Fig. 1 Alignment of a frutalin-deduced amino acid sequence (clone A) with sequences of the galactose-binding plant lectins jacalin and mornigaG ( $a$ - this work; $b$-Yang and Czapla [16]; $c$ - Van Damme et al. [20]). The amino acid residues are represented by the one-letter code. The shaded amino acids represent the four amino acid linker connecting $\beta$ - and $\alpha$-chains. The underlined amino acids in the frutalin sequence correspond to a glycosylation consensus sequence. The amino acids that are conserved between the different lectins are in bold and marked in the "consensus" line by an asterisk
Table 2 Amino acid substitutions in three frutalin codifying genes (clone A, B and $\mathrm{C})$, relative to an amino acid sequence of mature frutalin protein
The names of the amino acid residues are abbreviated and "+" signal is used when the amino acid is identical to the same position in the mature sequence

\begin{tabular}{lllll}
\hline $\begin{array}{l}\text { Residue number } \\
\text { (N- to C-terminal) }\end{array}$ & $\begin{array}{l}\text { Mature } \\
\text { sequence }\end{array}$ & Clone A & Clone B & Clone C \\
\hline 2 & Gln & Glu & Glu & Glu \\
18 & Lys & + & + & Gln \\
55 & Val & Ile & Ile & Ile \\
61 & Ser & Arg & + & Arg \\
63 & Tyr & Phe & + & Phe \\
69 & Lys & Thr & Ala & Thr \\
73 & Thr & Lys & Lys & Lys \\
81 & Ser & + & + & Ala \\
90 & Met & Val & Val & Ile \\
95 & Tyr & His & His & His \\
98 & Asn & Lys & Lys & Lys \\
107 & Ser & + & Pro & + \\
109 & Thr & + & Val & Ala \\
137 & Ile & Val & Met & + \\
148 & Leu & Met & + \\
\hline
\end{tabular}

expression in $E$. coli. The amino acid sequence consisted of the $\beta$-chain (20 amino acids) connected to the $\alpha$-chain (133 amino acids) by the linker tetrapeptide "T-S-S-N" (Fig. 1). The frutalin codifying DNA was re-amplified by PCR and inserted into the multiple cloning site of the E. coli expression vector $(\mathrm{pET} 25 \mathrm{~b}(+))$. Two changes were introduced in the frutalin cDNA during re-amplification. Alanine was used as terminal amino acid instead of aspargine to prevent bacterial expression problems due to the $\mathrm{N}$-end rule [26, 27], and a stop codon was placed at the last $3^{\prime}$ position of the frutalin gene for frutalin expression in bacteria with its native $\mathrm{C}$-terminal. The dideoxy nucleotide sequencing has confirmed the cloning strategy employed to clone frutalin in E. coli. The expression vector used $(\mathrm{pET} 25 \mathrm{~b}(+))$ has a peIB signal sequence to target the recombinant lectin to the periplasmic space. The peIB sequence is usually cleaved after the recombinant proteins are exported to the periplasmic space. This vector also has the strong promoter T7lac which can be induced by the presence of IPTG.

The cloned frutalin cDNA sequence has a high content of codons of rare utilisation by $E$. coli. Hence, to minimise expression limitations due to codon bias utilisation, the bacterial strain E. coli BL21-CodonPlus(DE3)-RIPL 

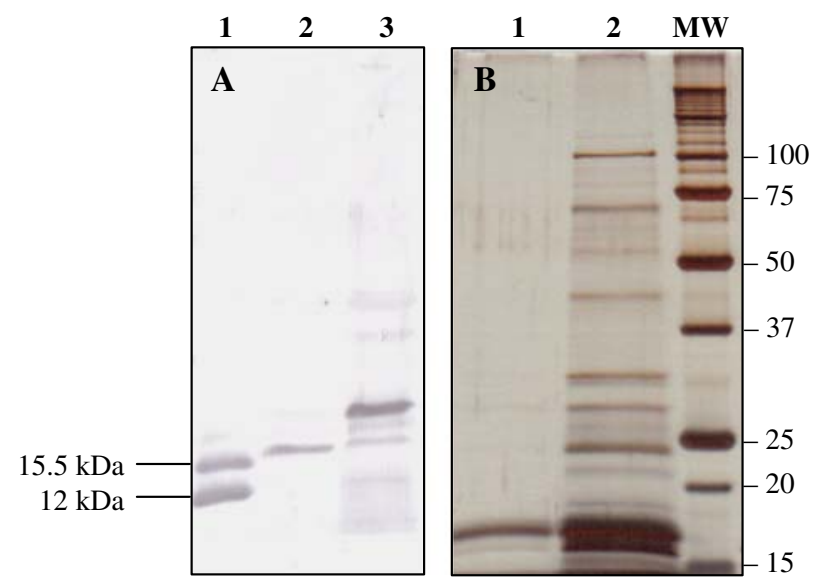

Fig. 2 Analysis of the recombinant frutalin produced by E. coli at the optimal culture conditions ( $1 \mathrm{mM}$ IPTG, $20 \mathrm{~h}, 22^{\circ} \mathrm{C}$ ). a Recombinant frutalin expression analysis by Western blot. 1 Native frutalin isolated from $A$. incisa seeds; $2 \mathrm{E}$. coli soluble fraction; $3 \mathrm{E}$. coli insoluble fraction. b SDS-PAGE gel of the recombinant frutalin purification from the $E$. coli cell-free extracts (silver nitrate stained). $M W$ molecular weight marker $(\mathrm{kDa}) ; 1$ Purified recombinant frutalin; 2 Partly purified recombinant frutalin

(Stratagene), which contains extra copies of $\arg U$ (AGA, AGG), ileY (AUA), leuW (CUA) and proL (CCC) tRNA genes, was chosen for frutalin expression.

The presence of recombinant frutalin in the E. coli extracts was confirmed by Western blot analysis using a polyclonal anti-frutalin serum (Fig. 2). As shown in Fig. 2, frutalin was successfully expressed in E. coli, in the soluble fraction (Fig. 2a, lane 2), with an apparent molecular weight slightly higher than native frutalin (Fig. 2a, lane 1). The presence of the linker between $\alpha$ - and $\beta$-chains would lead to this molecular weight difference. A larger and higher molecular mass band with an apparent weight of about $19 \mathrm{kDa}$ (Fig. 2a, lane 3) can also be seen in the insoluble fraction. This band may correspond to the unprocessed frutalin (where the peIB leader sequence was not cleaved). Significant amounts of recombinant lectin accumulated as insoluble protein within all the different culture conditions tested (data not shown).

\section{Optimisation of the Soluble Recombinant Frutalin Expression}

The expression of soluble recombinant frutalin in E. coli was optimised through an experimental factorial design. The two-level combinations of the three studied culture conditions factors (concentration of IPTG, temperature and time of induction) resulted in the model matrix and in the responses presented in Table 3. This table shows that the three highest values of soluble recombinant frutalin concentration were obtained in assays 1, 3 and 7. In these three assays, the induction occurred at the lowest temperature.
Table 3 Model matrix and concentration response for each experiment obtained in the experimental factorial design implemented for the optimisation of soluble recombinant frutalin expression in E. coli

\begin{tabular}{lllll}
\hline $\begin{array}{l}\text { Experiment } \\
\text { number }\end{array}$ & $x_{1}$ & $x_{2}$ & $x_{3}$ & $\begin{array}{l}\text { Concentration of } \\
\text { recombinant } \\
\text { frutalin }(\mathrm{mg} / \mathrm{l})\end{array}$ \\
\hline 1 & - & - & - & 13.0 \\
2 & + & - & - & 11.9 \\
3 & - & + & - & 12.4 \\
4 & + & + & - & 11.8 \\
5 & - & - & + & 7.92 \\
6 & + & - & + & 6.29 \\
7 & - & + & + & 16.0 \\
8 & + & + & + & 11.2 \\
9 & 0 & 0 & 0 & 12.4
\end{tabular}

"_" signal corresponds to the lower level experimental domain, "+" signal to the upper level experimental domain and " 0 " corresponds to the centre point level, for each variable

Assays 1 and 3 also had in common the lower level for the time of induction, whereas assays 3 and 7 had in common the upper level for the concentration of IPTG.

The relationship between the variables and the responses was linear as the response values obtained for the centre point level experiment were within the mean value range obtained for responses of the eight independent experiments [28]. The estimation of the average effect, the effect of each individual variable on the response (the main effects) and the effect of their respective interactions were calculated according to Lundstedt et al. [28] and further evaluated by the Design Expert program. The results obtained from the statistical analysis are presented in Table 4 . The Model $F$-value obtained from this analysis (11.61) implies that the model is significant. As shown in Table 4, all the three main factors (the IPTG concentration, the temperature and the time of induction) had statistical significance $(98.8 \%$ of confidence level). The IPTG concentration was the most statistically significant factor as its effect on recombinant frutalin soluble expression $(P=0.0006)$ was considerably higher than the other main effects $(P>0.008)$. The concentration of IPTG had a positive influence on the process, as soluble recombinant frutalin concentration was higher for increased IPTG concentration. On the other hand, temperature and time of induction had a negative effect because higher soluble recombinant frutalin concentration values were obtained with decreased temperature and time of induction. Amongst the interactions, only the interaction between the concentration of IPTG and the time of induction had statistical significance $(99.97 \%$ of confidence level). This interaction had a positive influence on soluble recombinant frutalin concentration and was also the most significant variable in all factorial design $(P=0.0003)$. 
Table 4 Statistical analysis of the $2^{3}$ factorial design implemented for the optimisation of soluble recombinant frutalin expression in $E$. coli, using the Design Expert software

\begin{tabular}{|c|c|c|c|c|c|c|}
\hline Factor/Source & Coefficient & Standard error & $\mathrm{SS}^{\mathrm{a}}$ & d.f. ${ }^{b}$ & $F$-value ${ }^{\text {c }}$ & $P^{\mathrm{d}}$ \\
\hline Intercept & 11.31 & 0.31 & - & - & - & - \\
\hline$x_{1}$ : Temperature of induction & -1.01 & 0.31 & 16.34 & 1 & 10.55 & 0.0087 \\
\hline$x_{2}:$ IPTG concentration & 1.52 & 0.31 & 37.03 & 1 & 23.91 & 0.0006 \\
\hline$x_{3}:$ Time of induction & -0.96 & 0.31 & 14.66 & 1 & 9.46 & 0.0117 \\
\hline$x_{1} x_{2}$ & -0.32 & 0.31 & 1.59 & 1 & 1.03 & 0.3347 \\
\hline$x_{1} x_{3}$ & -0.58 & 0.31 & 5.43 & 1 & 3.50 & 0.0908 \\
\hline$x_{2} x_{3}$ & 1.72 & 0.31 & 47.42 & 1 & 30.61 & 0.0003 \\
\hline$x_{1} x_{2} x_{3}$ & -0.46 & 0.31 & 3.37 & 1 & 2.17 & 0.1712 \\
\hline Model & - & - & 125.84 & 7 & 11.61 & 0.0004 \\
\hline
\end{tabular}

$R^{2}=0.89 ;$ C.V. $=10.85 \%$

a Sum of squares

b Degrees of freedom

c Fisher's statistical parameter

d Confidence level

The results obtained were evaluated to fit in a thirdorder interaction model, describing the experimental response [28]. Only the effects and interactions significant for the soluble expression of recombinant frutalin were included in the polynomial model, resulting in

$y=11.31-1.01 x_{1}+1.52 x_{2}-0.96 x_{3}+1.72 x_{2} x_{3}$

where $y$ represents the concentration response obtained for soluble recombinant frutalin $(\mathrm{mg} / \mathrm{l}), x_{1}$ is the temperature of induction, $x_{2}$ is the concentration of IPTG, $x_{3}$ is the time of induction and $x_{2} x_{3}$ is the interaction between the concentration of IPTG and the time of induction. This model gave the best fitting response function for the significant main effects and interactions and it was significant at a confidence level of 99.96\% $(P=0.0004)$. The maximum soluble recombinant frutalin yield was obtained at $22^{\circ} \mathrm{C}$ and $20 \mathrm{~h}$ of induction with $1 \mathrm{mM}$ IPTG (16 mg/l). These same parameters values were also predicted by the Design Expert program.

\section{Purification of the Recombinant Frutalin}

Size-exclusion chromatography was implemented as the preliminary step in the purification of recombinant frutalin from the E. coli cell-free extracts. It resulted in approximately $50 \mathrm{ml}$ of pooled fractions with hemagglutination activity per litre of recombinant $E$. coli culture. Some of these fractions presented a high level of purity, showing that most of the native E. coli proteins were removed; nevertheless, the majority of the fractions needed further purification and concentration steps. Hence, ion-exchange chromatography was conducted to purify recombinant frutalin from the resulting size-exclusion chromatography fractions. At a $\mathrm{pH}$ value of 5.0, both native and recombinant frutalin bound to the ion-exchange column. It was necessary to decrease the $\mathrm{pH}$ of the samples containing frutalin to 5.0, as a pH value of 7.4 or 6.0 was not sufficient to make frutalin bind to the MonoS column despite the differences of 1.35 and 2.75 units between these $\mathrm{pH}$ values and the predicted frutalin $\mathrm{p} I$ (8.75), respectively. The $\mathrm{p} I$ determined to native frutalin was 8.8-9.0 [5]. However, at a $\mathrm{pH}$ value of 5.0, frutalin can be partially or totally denaturated, as weak or no hemagglutination activity was detected in recombinant frutalin samples after the $\mathrm{pH}$ had been decreased to this value. The refolding of purified recombinant frutalin was successfully made by intensive dialysis against PBS buffer. Up to $76 \mu \mathrm{g}$ of active recombinant frutalin per litre of $E$. coli culture was obtained using the described purification strategy. Recombinant frutalin migrated on SDS-PAGE gels as a homogeneous single-band protein with a molecular mass of about $17 \mathrm{kDa}$ (Fig. 2b, lane 1). This is consistent with the predicted molecular weight of the cloned frutalin sequence. Unlike native frutalin, the $\alpha$ - and $\beta$-chains of the recombinant lectin are probably linked by the "T-S-S-N" linker peptide, making a single-chain protein, as occurred with jacalin expressed in E. coli [11]. We have previously reported the expression of frutalin in Pichia pastoris where a partly glycosylated single-chain protein was obtained [10]. Frutalin does not undergo any proteolytic cleavage in either E. coli, or Pichia, so it is highly possible that the linker cleavage may be a specific processing step of higher eukaryotes.

\section{Hemagglutination Assays}

Recombinant frutalin was also detected in the soluble fraction of the E. coli extracts by hemagglutination assays, 
Table 5 Effect of different carbohydrates on the hemagglutination activity (HA) of recombinant and native frutalin (with inhibition: -; without inhibition: + )

\begin{tabular}{lll}
\hline Carbohydrate $(125 \mathrm{mM})$ & Effect on native frutalin HA & Effect on recombinant frutalin HA \\
\hline D-Glucose & + & + \\
D-Galactose & - & - \\
D-Mannose & + & + \\
Me- $\alpha$-galactose & - & - \\
Melibiose & - & - \\
Lactose & + & + \\
\hline
\end{tabular}

using rabbit erythrocytes. Interestingly, the agglutination of these cells was only obtained after a dilution factor of two or four times, suggesting the presence of agglutination inhibitory components. As recombinant frutalin showed the native frutalin ability to agglutinate rabbit erythrocytes, contrary to the glycosylated yeast frutalin [10], it can be concluded that the linker cleavage is not essential for the hemagglutination activity of frutalin.

The carbohydrate-binding specificity of recombinant frutalin, purified from the $E$. coli cell-free extracts, was determined by inhibition assays of the rabbit erythrocytes agglutination using different sugars. Of all the sugars tested, D-glucose, D-mannose and D-lactose, at a final concentration of $125 \mathrm{mM}$, did not inhibit the hemagglutination activity of the recombinant frutalin. On the other hand, D-galactose, Me- $\alpha$-galactose and melibiose (gal $\alpha 1-6$ glu), at a final concentration of $125 \mathrm{mM}$, unequivocally inhibited the recombinant frutalin agglutinating activity. The same results were obtained for native frutalin (Table 5). Thus, as native frutalin, recombinant frutalin is also a galactose-binding lectin. However, it was not possible to purify the recombinant frutalin by affinity chromatography on Adenanthera pavonina galactomannan, making use of its hypothetical specificity to galactose, either directly from the $E$. coli cell-free extracts or from chromatography resulting fractions, using the same procedure described for native frutalin [5]. Recombinant frutalin was always easily removed from the galactomannan gum with PBS buffer during the washing steps (data not shown). This result suggests that recombinant frutalin has a lower sugar-binding affinity than the native frutalin lectin. This is corroborated by data obtained from sugar affinity studies made with recombinant galactose-binding jacalinrelated lectins, which showed that the presence of the linker significantly reduced their native carbohydrate affinities $[10,11]$. Nevertheless, the sugar-binding specificity of the recombinant frutalin produced by $E$. coli was maintained, and therefore its functionality was preserved.

\section{Conclusions}

This is the first time that frutalin cDNA is described and analysed. Different cDNA clones, sharing 94-97\% of sequence identity, have been isolated from the breadfruit seeds cDNA library. Alignment of the frutalin-deduced amino acid sequences with sequences of other galactosebinding jacalin-related lectins revealed the existence of several conserved regions.

Soluble recombinant frutalin was successfully expressed in E. coli by cDNA cloning. On the basis of the experimental design responses, the optimum conditions to obtain the maximum yield of soluble recombinant frutalin were: induction with $1 \mathrm{mM}$ of IPTG at $22^{\circ} \mathrm{C}$ for $20 \mathrm{~h}$. At these conditions, a twofold increase in soluble recombinant frutalin expression was obtained $(16 \mathrm{mg} / \mathrm{l})$. Hemagglutination assays made with recombinant frutalin revealed that it has a carbohydrate-binding specificity qualitatively identical to the native frutalin lectin. Thus, functional frutalin can be easily produced in the heterologous $E$. coli expression system. However, further improvements are needed to increase the amount of pure recombinant frutalin obtained.

Acknowledgements Carla Oliveira was supported by the grant SFRH/BD/19099/2004 from Fundação para a Ciência e a Tecnologia, Portugal. We thank Wagner Felix and Prof. Renato Moreira (Universidade de Fortaleza, Brazil) for the RT-PCR reaction and for providing breadfruit seeds.

\section{References}

1. Peumans, W. J., \& Van Damme, E. J. M. (1995). Lectins as plant defense proteins. Plant Physiology, 109, 347-352. doi:10.1104/ pp.109.2.347.

2. Chandra, N. R., Kumar, N., Jeyakani, J., Singh, D. D., Gowda, S. B., \& Prathima, M. N. (2006). Lectindb: a plant lectin database. Glycobiology, 16, 938-946. doi:10.1093/glycob/cwl012.

3. Van Damme, E. J. M., Peumans, W. J., Barre, A., \& Rougé, P. (1998). Plant lectins: a composite of several distinct families of structurally and evolutionary related proteins with diverse biological roles. Critical Reviews in Plant Sciences, 17, 575-692. doi:10.1016/S0735-2689(98)00365-7.

4. Rüdiger, H., \& Gabios, H. J. (2001). Plant lectins: occurrence, biochemistry, functions and applications. Glycoconjugate Journal, 18, 589-613. doi:10.1023/A:1020687518999.

5. Moreira, R. A., Castelo-Branco, C. C., Monteiro, A. C. O., Tavares, R. O., \& Beltramini, L. M. (1998). Isolation and partial characterization of a lectin from Artocarpus incisa L. seeds. Phytochemistry, 47, 1183-1188. doi:10.1016/S0031-9422(97)00 753-X. 
6. Pineau, N., Pousset, J. L., Preud'Homme, J. L., \& Aucouturier, P. (1990). Structural and functional similarities of breadfruit seed lectin and jacalin. Molecular Immunology, 27, 237-240. doi: 10.1016/0161-5890(90)90135-M.

7. Campana, P. T., Moraes, D. I., Monteiro-Moreira, A. C. O., \& Beltramini, L. M. (2002). Unfolding and refolding studies of frutalin, a tetrameric D-galactose binding lectin. European Journal of Biochemistry, 269, 753-758. doi:10.1046/j.0014-2956. 2002.02742.x.

8. Brando-Lima, A. C., Saldanha-Gama, R. F., Henriques, M. G. M. O., Monteiro-Moreira, A. C. O., Moreira, R. A., \& Barja-Fidalgo, C. (2005). Frutalin, a galactose-binding lectin, induces chemotaxis and rearrangement of actin cytoskeleton in human neutrophils: Involvement of tyrosine kinase and phosphoinositide 3-kinase. Toxicology and Applied Pharmacology, 208, 145-154. doi:10.1016/j.taap.2005.02.012.

9. Brando-Lima, A. C., Saldanha-Gama, R. F., Pereira, C. R., Villela, C. G., Sampaio, A. L. F., Monteiro-Moreira, A. C. O., et al. (2006). Involvement of phosphatidylinositol-3 kinase-Akt and nuclear factor kappa-B pathways in the effect of frutalin on human lymphocyte. International Immunopharmacology, 6, 465472. doi:10.1016/j.intimp.2005.09.008.

10. Oliveira, C., Felix, W., Moreira, R. A., Teixeira, J. A., \& Domingues, L. (2008). Expression of frutalin, an $\alpha$-D-galactosebinding jacalin-related lectin, in the yeast Pichia pastoris. Protein Expression and Purification, 60, 188-193. doi:10.1016/j.pep. 2008.04.008.

11. Sahasrabuddhe, A. A., Gaikwad, S. M., Krishnasastry, M. V., \& Khan, M. I. (2004). Studies on recombinant single chain jacalin lectin reveal reduced affinity for saccharides despite normal folding like native Jacalin. Protein Science, 13, 3264-3273. doi: 10.1110/ps.04968804.

12. Luo, S., Zhangsun, D., \& Tang, K. (2005). Functional GNA expressed in Escherichia coli with high efficiency and its effect on Ceratovacuna lanigera Zehntner. Applied Microbiology and Biotechnology, 69, 184-191. doi:10.1007/s00253-005-0042-6.

13. Jiang, J.-F., Han, Y., Xing, L.-J., Xu, Y.-Y., Xu, Z.-H., \& Chong, K. (2006). Cloning and expression of a novel cDNA encoding a mannose-specific jacalin-related lectin from Oryza sativa. Toxicon, 47, 133-139. doi:10.1016/j.toxicon.2005.10.010.

14. Lin, L., Lu, J., Zeng, H., Liang, Z., Zhou, Y., Lin, J., et al. (2008). Molecular cloning and characterization of a mannose-binding lectin gene from Pinellia cordata. Molecular Biology Reports, 35, 641-647. doi:10.1007/s11033-007-9134-y.

15. Houlès Astoul, C., Peumans, W. J., Van Damme, E. J. M., Barre, A., Bourne, Y., \& Rougé, P. (2002). The size, shape and specificity of the sugar-binding site of the jacalin-related lectins is profoundly affected by the proteolytic cleavage of the subunits. The Biochemical Journal, 367, 817-824. doi:10.1042/BJ200 20856.

16. Yang, H., \& Czapla, T. H. (1993). Isolation and characterization of cDNA clones encoding jacalin isolectins. The Journal of Biological Chemistry, 268, 5905-5910.

17. Ruffet, E., Paquet, N., Frutiger, S., Hughes, G. J., \& Jaton, J.-C. (1992). Structural and electron-microscopic studies of jacalin from jackfruit (Artocarpus integrifolia) show that this lectin is a $65 \mathrm{kDa}$ tetramer. The Biochemical Journal, 286, 131-134.

18. Young, N. M., Johnston, R. A. Z., \& Watson, D. C. (1991). The amino acid sequences of jacalin and the Maclura pomifera agglutinin. FEBS Letters, 282, 382-384. doi:10.1016/0014-5793 (91)80518-8.

19. Mahanta, S. K., Sanker, S., Rao, N. V., Swamy, M. J., \& Surolia, A. (1992). Primary structure of a Thomsen-Friedenreich-antigenspecific lectin, jacalin [Artocarpus integrifolia (jack fruit) agglutinin]. Evidence for the presence of an internal repeat. The Biochemical Journal, 284, 95-101.

20. Van Damme, E. J. M., Hause, B., Hu, J., Barre, A., Rougé, P., Proost, P., et al. (2002). Two distinct jacalin-related lectins with a different specificity and subcellular location are major vegetative storage proteins in the bark of the black mulberry tree. Plant Physiology, 130, 757-769. doi:10.1104/pp.005892.

21. Abdul Rahman, M., Anuar Karsani, S., Othman, I., Shafinaz Abdul Rahman, P., \& Haji Hashim, O. (2002). Galactose-binding lectin from the seeds of champedak (Artocarpus integer): sequences of its subunits and interactions with human serum O-glycosylated glycoproteins. Biochemical and Biophysical Research Communications, 295, 1007-1013. doi:10.1016/S0006291X(02)00795-7.

22. Ngoc, L. D., Brillard, M., \& Hoebeke, J. (1993). The $\alpha$ and $\beta$-subunits of jacalins are cleavage products from a $17-\mathrm{kDa}$ precursor. Biochimica et Biophysica Acta, 1156, 219-222.

23. daSilva, L. L. P., Molfetta-Machado, J. B., Panunto-Castelo, A., Denecke, J., Goldman, G. H., Roque-Barreira, M.-C., et al. (2005). cDNA cloning and functional expression of $\mathrm{KM}+$, the mannose-binding lectin from Artocarpus integrifolia seeds. Biochimica et Biophysica Acta, 1726, 251-260.

24. Sahasrabuddhe, A. A., Ahmed, N., \& Krishnasastry, M. V. (2006). Stress-induced phosphorylation of caveolin-1 and p38, and down-regulation of EGFr and ERK by the dietary lectin jacalin in two human carcinoma cell lines. Cell Stress \& Chaperones, 11, 135-147. doi:10.1379/CSC-160R.1.

25. Yin, J., Li, G., Ren, X., \& Herrler, G. (2007). Select what you need: A comparative evaluation of the advantages and limitations of frequently used expression systems for foreign genes. Journal of Biotechnology, 127, 335-347. doi:10.1016/j.jbiotec.2006. 07.012.

26. Tobias, J. W., Shrader, T.-E., Rocap, G., \& Varshavsky, A. (1991). The N-end rule in bacteria. Science, 254, 1374-1377. doi: 10.1126/science. 1962196.

27. Hirel, P.-H., Schmitter, J.-M., Dessen, P., Fayat, G., \& Blanquet, S. (1989). Extent of N-terminal methionine excision from Escherichia coli proteins is governed by the side-chain length of the penultimate amino acid. Proceedings of the National Academy of Sciences of the United States of America, 86, 8247-8251. doi: 10.1073/pnas.86.21.8247.

28. Lundstedt, T., Seifert, E., Abramo, L., Thelin, B., Nyström, A., Pettersen, J., et al. (1998). Experimental design and optimization. Chemometrics and Intelligent Laboratory Systems, 42, 3-40. doi: 10.1016/S0169-7439(98)00065-3. 